\title{
The expression of integrins is decreased in colon cancer cells treated with polysaccharide $K$
}

\author{
KEIKO ASO, TAKANORI GOI, TOSHIYUKI NAKAZAWA, YOUHEI KIMURA, \\ YASUO HIRONO, KANJI KATAYAMA and AKIO YAMAGUCHI
}

First Department of Surgery, University of Fukui, Yoshida-gun, Fukui, Japan

Received October 20, 2012; Accepted December 7, 2012

DOI: 10.3892/ijo.2013.1832

\begin{abstract}
Polysaccharide K (PSK), a protein-bound polysaccharide used as a non-specific immunotherapeutic agent, is said to improve the prognosis of malignant tumors such as colon cancer, but there have been few in-depth investigations of its mechanism of action. In the present study, we investigated which genes in colon cancer cells themselves are regulated by PSK and what sort of action it exerts. Colon cancer cells were exposed to PSK in vitro and changes to their morphology and adhesive capacity were investigated, as were the changes in integrin expression that occurred. Exposure to PSK caused colon cancer cells to become spherical in morphology and investigation of their adhesion rate showed that it reduced adhesion to laminin, fibrinogen, collagen IV, collagen I and fibronectin. In terms of changes to molecules on the surface of cancer cells, there was reduced expression of integrin mRNA $\alpha$ and $\beta$, which are ligands for the proteins of basement membrane. An investigation of the adhesiveness of PSK-stimulated colon cancer cells to vascular endothelial cells also showed that the adhesion rate decreased significantly compared with cells not exposed to PSK. Suppression of integrin expression on the cell surface and reduced adhesion to vascular endothelial cells were observed as a novel mechanism of action of PSK on colon cancer cells.
\end{abstract}

\section{Introduction}

Colon cancer has an important position among malignant disorders in Japan, the United States and Europe and is treated by a range of therapies including surgery, chemotherapy and radiotherapy (1-8).

Polysaccharide K (PSK), a protein-bound polysaccharide, is a widely used, non-specific immunotherapeutic agent that

Correspondence to: Dr Takanori Goi, First Department of Surgery, University of Fukui, 23-3 Eiheiji-cho, Yoshida-gun, Fukui, Japan E-mail: tgoi@u-fukui.ac.jp

Key words: colon cancer, polysaccharide $\mathrm{K}$, adhesion molecule, integrin is obtained from Coriolus versicolor fungi (9). In structure, it includes a protein-bound polysaccharide with a molecular weight of approximately 94,000 , containing approximately $38 \%$ protein, with the sugar portion being a $\beta$-glycan glucose that contains around $75 \%$ glucose in addition to mannose, xylose and galactose.

To date, the major known mechanisms of action of PSK include: i) apoptosis induction, inhibition of cell invasion and enhanced expression of MHC class I; ii) enhanced activation of natural killer, cytotoxic T, lymphokine-activated killer and other cells as an effect of cytokine induction involved with immunocyte and host defense regulation, as well as regulation of cytokine production; and iii) inhibition of TGF- $\beta$ production and alleviation of oxidative stress by inhibition of immunosuppressive substances, and it possesses a diverse range of immunostimulating effects as a biochemical response modifier (10-13). In terms of clinical knowledge, Torisu et al compared a group of patients given PSK as monotherapy after colon cancer curative resection with a group not given PSK, and found that the PSK-treated group had a significantly better survival rate (14). Sakamoto et al, Ohwada et al and Yoshitani et al also reported that, when PSK was combined with anticancer drugs after colon cancer curative resection, patients who received PSK had significantly better survival rates than did those who did not receive it (15-17). Other reports describe the efficacy of PSK administration with respect to gastric, esophageal, breast and lung cancer (18-22). That is, PSK has been shown to contribute to the treatment of a variety of malignant tumors from the perspectives of both basic science experiments and clinical results.

Few reports, however, have addressed the genetic changes that occur in colon cancer cells themselves as a result of PSK administration. In the present study, we investigated which genes in colon cancer cells themselves are acted on by PSK and what kind of action it exerts.

\section{Materials and methods}

Cell viability. Apoptosis was detected by cytometry using Annexin-V-Fluos staining kit (Roche, Germany). Briefly, cells were incubated with Annexin-V-Alexa 568 for $15 \mathrm{~min}$. After cells were washed thrice in PBS, we detected red cells under a fluorescent microscope. 
Cell culture. The human colorectal cancer cell lines: HCT116, HT29 and DLD-1 (obtained from European Collection of Cell Cultures, UK) were cultured at $37^{\circ} \mathrm{C}$ in $5 \% \mathrm{CO}_{2}$ in RPMI-1640 medium containing $10 \%$ fetal bovine serum (23).

We attest that the research was performed in accordance with the humane and ethical rules for human experimentation that are stated in the Declaration of Helsinki.

Cell treatment and cell morphology. The cells were plated in 10-cm tissue culture dish and co-cultured with $300 \mu \mathrm{g} / \mathrm{ml}$ PSK (Kureha Chemical Industry, Co., Ltd., Tokyo, Japan). After $16 \mathrm{~h}$, the cell morphology was digitally photographed at x200 magnification.

Cell adhesion assay. CytoSelect 48-Well cell adhesion assay (ECM Array: Cell Biolabs Inc., San Diego, CA, USA) was performed for $10 \mathrm{~min}$ at room temperature. An aliquot $\left(5 \times 10^{4}\right.$ cells) of the prepared cell suspension was added into the well, as an adhesive substrate for $8 \mathrm{~h}$ at $37^{\circ} \mathrm{C}$ in a cell culture incubator. Adherent cells were stained and quantified at OD560 after extraction according to the manufacturer's instructions.

$R T^{2}$ Profiler $^{T M}$ PCR array and real-time PCR. Total-RNA was extracted from colon cancer cells using guanidinium-thiocyanate $(23,24)$. Real-time PCR was performed according to the User Manual of $\mathrm{RT}^{2}$ Profiler PCR array system (Extracellular Matrix and Adhesion Molecule PCR array: Catalog no. PAHS-013A) (SABioscience, Frederick, MD, USA). The data were analyzed using Excel-based PCR Array Data Analysis Templates.

Tumor cell-endothelium adhesion assays. Tumor cell-endothelium adhesion assays were carried out according to the manufacturer's instructions (Cell Biolabs, Inc.). In brief, human venous endothelial cells (HUVEC) $\left(5 \times 10^{4}\right)$ were seeded onto the wells and were incubated at $37^{\circ} \mathrm{C}$ for $48 \mathrm{~h}$ in a tissue culture incubator. Harvest colon cancer cells $\left(1 \times 10^{6}\right.$ cells) were incubated in serum-free media with CytoTracker ${ }^{\mathrm{TM}}$ at $37^{\circ} \mathrm{C}$ for one hour. Colon cancer cells $\left(1 \times 10^{5}\right.$ cells) were seeded to the wells and were incubated at $37^{\circ} \mathrm{C}$ for $8 \mathrm{~h}$. After washing cancer cells, the adhesive cell number were counted at X100 magnification.

Statistical considerations. Characteristics of the two treatment arms were compared using the $\chi^{2}$ test. Values of $\mathrm{P}<0.05$ were considered as statistically significant.

\section{Results}

Cell viability. Colon cancer cells (HCT116, HT29 and DLD-1) analyzed under fluorescence microscope using Annexin-V-FLUOS staining assay showed no increased cell apoptosis and death in samples treated with PSK (average; $100 \mu \mathrm{g} / \mathrm{ml}$ : staining cells $1.5 \%$ or $300 \mu \mathrm{g} / \mathrm{ml}$ : staining cells $2.3 \%$ ) compared with untreated cells (staining cells $1.3 \%$ ). Cells treated with $500 \mu \mathrm{g} / \mathrm{ml}$ showed slightly increased cell apoptosis and death (staining cells $7.1 \%$ ).

Investigation of colon cancer cell morphology after PSK stimulation. We investigated the changes in cell morphology that (a) Non-stimulated
colon cancer cell

(1)

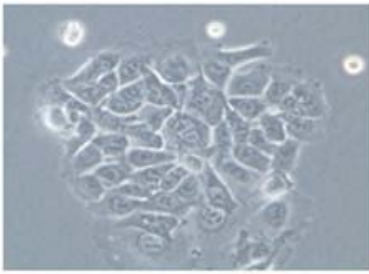

(2)

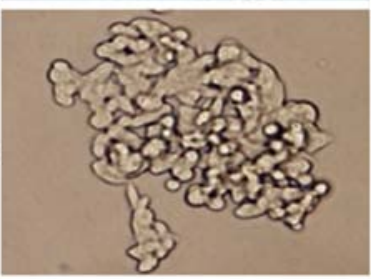

(3)

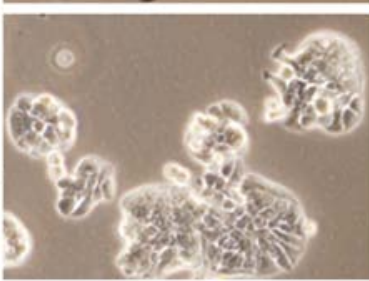

(b) PSK-stimulated colon cancer cell
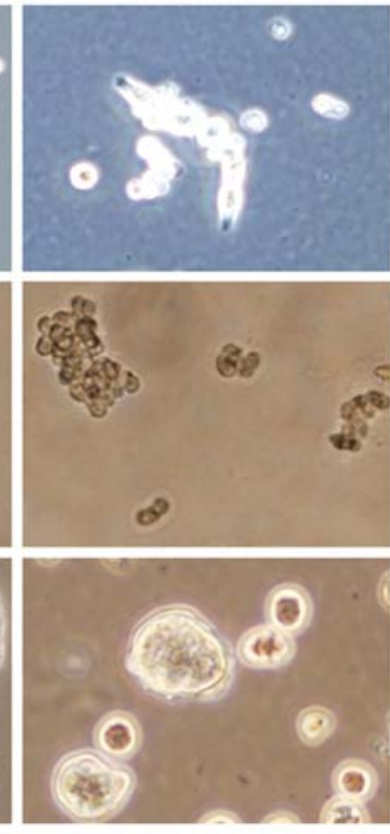

Figure 1. Colon cancer cell morphology after PSK stimulation. Colon cancer cells (1, HCT116; 2, HT29; 3, DLD-1) were plated and co-cultured with $300 \mu \mathrm{g} / \mathrm{ml}$ PSK for $16 \mathrm{~h}$. The cell morphology was photographed at $\mathrm{x} 200$ magnification. (a) Non-stimulated colon cancer cells. (b) PSK-stimulated colon cancer cells.

\section{Adhesion assay:HCT116}

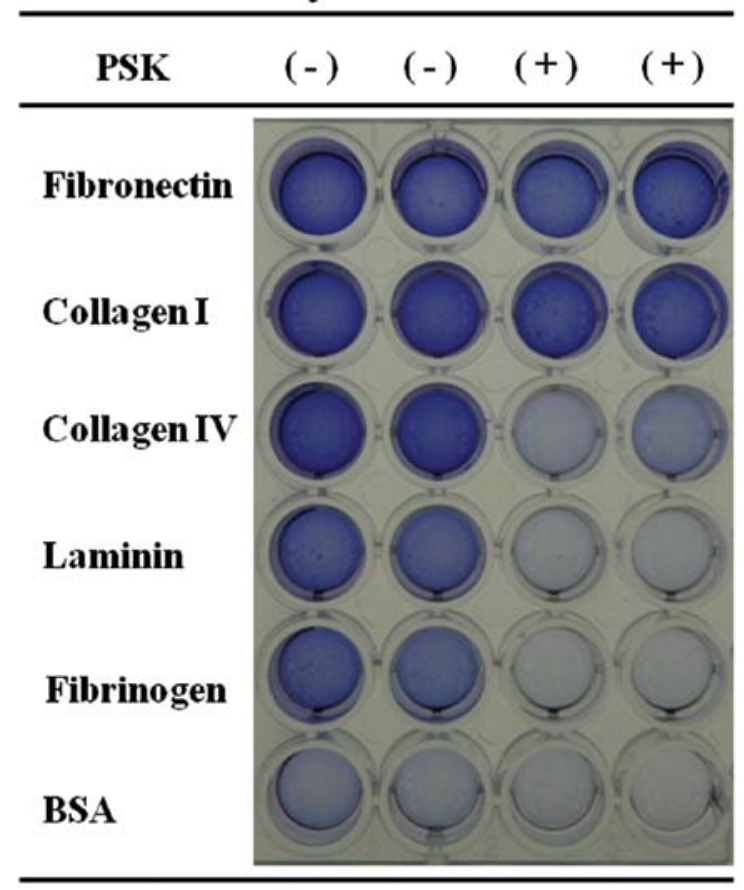

Figure 2. PSK-stimulated colon cancer cells reduce the adhesion of ECM proteins. Colon cancer cells (HCT116) treated with $500 \mu \mathrm{g} / \mathrm{ml}$ PSK for 6 days were allowed to attach in CytoSelect 48-Well cell adhesion assay for $8 \mathrm{~h}$ at $5 \times 10^{4}$ cells/well. After washing the cells, adherent cells were stained, and lysed. 

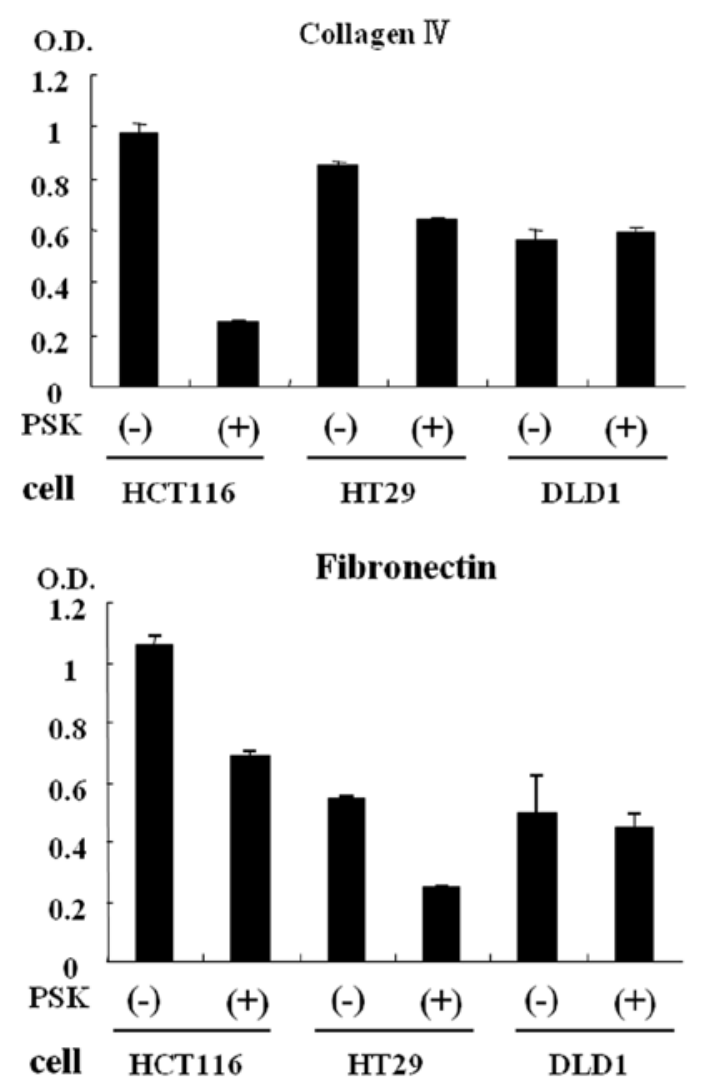

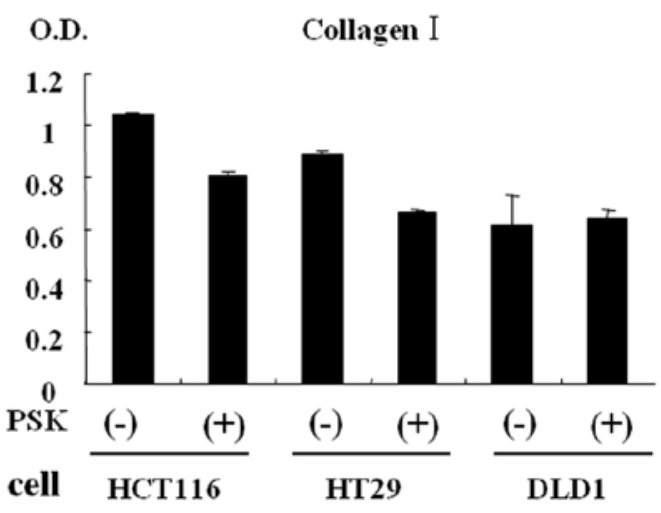

Laminin

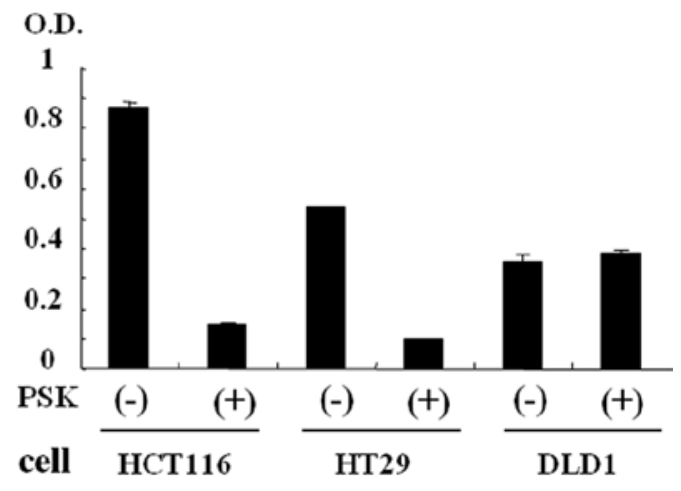

O.D.

Fibrinogen

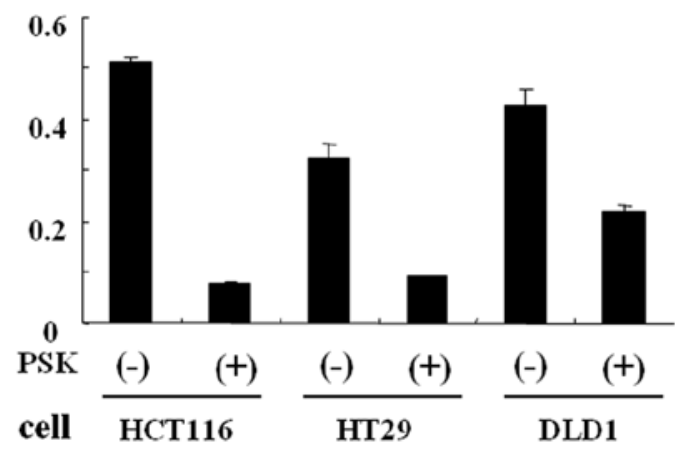

Figure 3. Adhesion rate of colon cancer cells after PSK stimulation. Adherent colon cancer cells (HCT116, HT29 and DLD-1) were stained, lysed and quantified at OD560 using Matrige CytoSelect 48-Well cell adhesion assay. occurred as a result of exposing colon cancer cells (HCT116, HT29, DLD-1) to PSK. The results are shown in Fig. 1. Non-stimulated colon cancer cells were fusiform in shape and exhibited intercellular adhesion, proliferating in sheet form, whereas PSK-stimulated colon cancer cells were spherical and exhibited reduced adhesion between cells.

Investigation of the adhesion rate of colon cancer cells after PSK stimulation. We investigated the cellular adhesion rate of colon cancer cells after PSK stimulation. The results are shown in Figs. 2 and 3. A comparison of non-stimulated colon cancer cells (HCT116 and HT29) and PSK-stimulated HCT116 or HT29 colon cancer cells showed reduced adhesion rates for laminin, fibrinogen, collagen IV, collagen I and fibronectin. A comparison of non-stimulated DLD-1 colon cancer cells and PSK-stimulated DLD-1 colon cancer cells showed that fibrinogen was the protein that showed the reduction in cellular adhesion.

Investigation of adhesion molecule integrin mRNA of colon cancer cells after PSK stimulation. The results mentioned above indicate the involvement of integrin mRNA, which are believed to be ligands for the substrates; therefore, the expression of each of these mRNAs was investigated (Fig. 4).

A comparison of non-stimulated HCT116 colon cancer cells with PSK-stimulated HCT116 colon cancer cells showed that expression of the integrin $\alpha-1,3,5$ and $\beta-1$ mRNA was significantly reduced in PSK-stimulated HCT116 colon cancer cells.

Non-stimulated HT29 colon cancer cells compared with PSK-stimulated HT29 colon cancer cells showed that expression of the integrin $\alpha-5$ and $\beta-1$ mRNA was significantly reduced in PSK-stimulated HT29 colon cancer cells. 

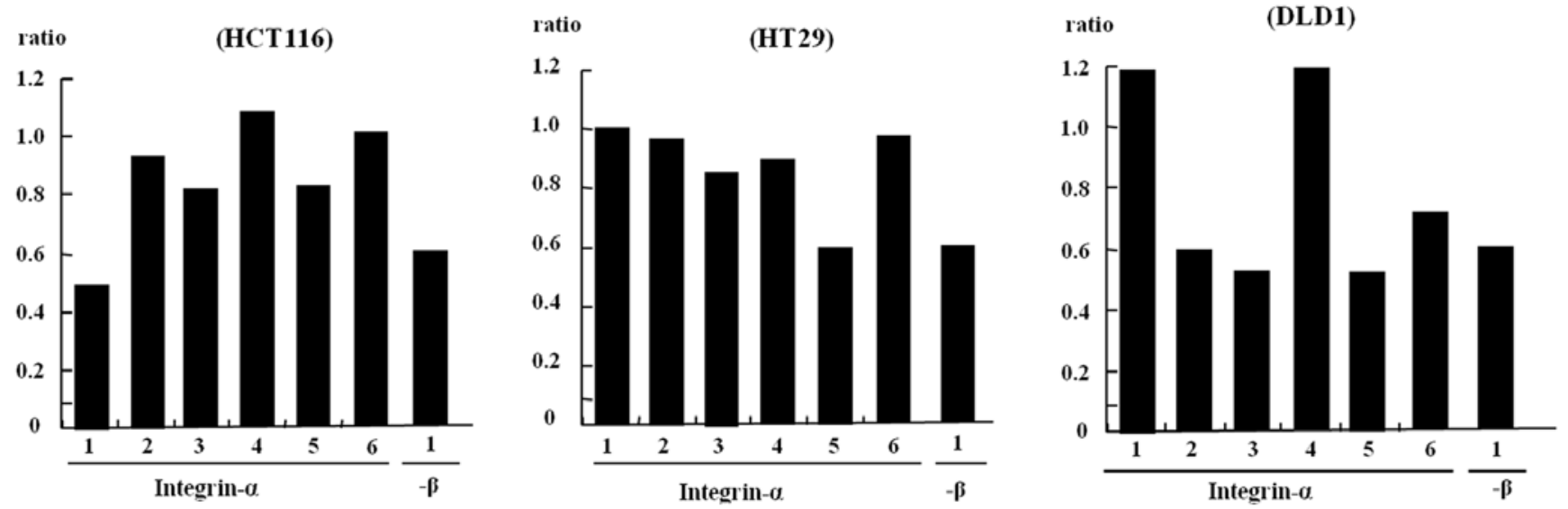

Figure 4. Expression of integrin mRNA in PSK-stimulate colon cancer cells. RNAs from non-stimulated colon cancer cells and PSK-stimulated colon cancer cells were treated with $\mathrm{RT}^{2}$ Profiler PCR array buffers. cDNAs were added to the wells in Extracellular Matrix and Adhesion Molecule PCR array. The data were analyzed using Excel-based PCR Array Data Analysis Templates. The expression rates of integrin $\alpha$ and $\beta$ are shown.

a

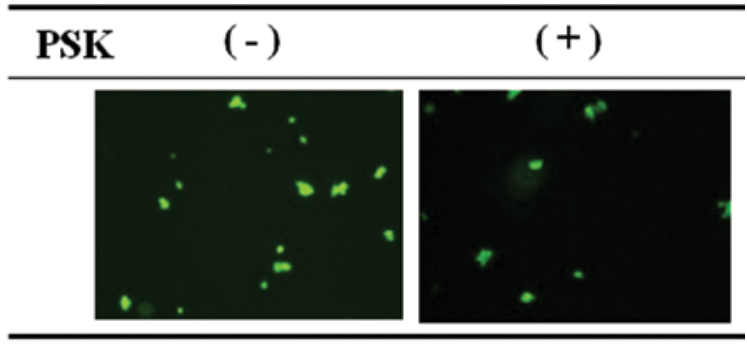

b

$(\mathbf{n}=\mathbf{4})$

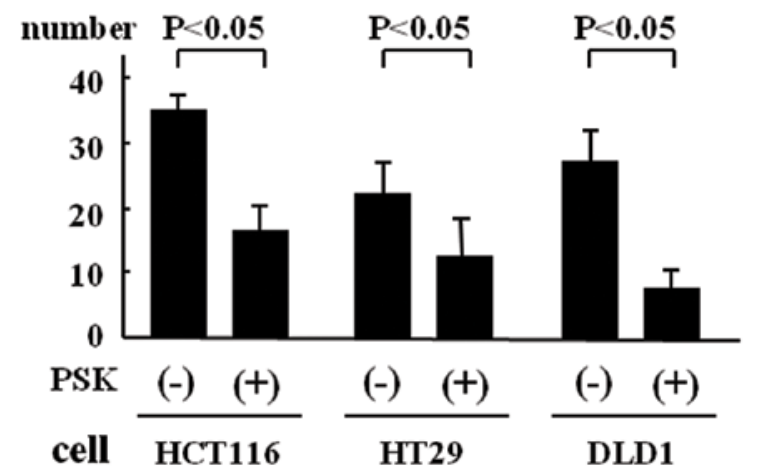

Figure 5. Adhesion of PSK-stimulate colon cancer cells to human venous endothelial cells. (a) Human venous endothelial cells $\left(5 \times 10^{4}\right)$ were seeded onto the wells and were incubated for $48 \mathrm{~h}$. PSK-stimulated colon cancer cells HCT116 $\left(1 \times 10^{5}\right.$ cells) were seeded to the wells and were incubated at $37^{\circ} \mathrm{C}$ for $8 \mathrm{~h}$. After washing cancer cells, the adhesive cell number were counted at x100 magnification. Left panel, non-stimulated colon cancer cells: HCT116; right panel, PSK-stimulated colon cancer cells: HCT116. (b) Number of colon cancer cells adherent to human venous endothelial cells. Each bar represents the mean number of adherent cells; error bar is SD.

A comparison of non-stimulated DLD-1 colon cancer cells with PSK-stimulated DLD-1 colon cancer cells showed that expression of the integrin $\alpha-2,3,5,6$ and $\beta-1$ mRNA was significantly reduced in PSK-stimulated DLD-1 colon cancer cells.

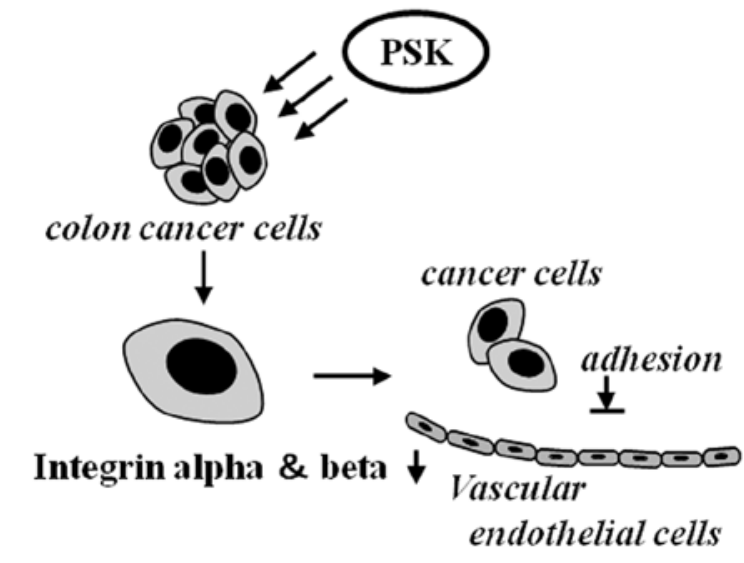

Figure 6. New actions of PSK. PSK-stimulated colon cancer cells reduce the integrin $\alpha$ and $\beta$ mRNA and reduce adhesion to vascular endothelial cells on the target organ.

Investigation of the adhesion rate of PSK-stimulated colon cancer cells to human vascular endothelial cells. We investigated the extent to which non-stimulated colon cancer cells and PSK-stimulated colon cancer cells adhered to human vascular endothelial cells. The results are shown in Fig. 5. The cell adhesion rate for non-stimulated HCT116 colon cancer cells was 34.5 cells/field of view, whereas for PSK-stimulated HCT116 colon cancer cells, it was 17.3 cells/field of view, a significantly lower rate of adhesion to HUVEC (Fig. 5b).

The cell adhesion rate for non-stimulated HT29 colon cancer cells was 21.4 cells/field of view, whereas for PSK-stimulated HT29 colon cancer cells, it was 11.8 cells/field of view, a significantly lower rate of adhesion to HUVEC. The cell adhesion rate for non-stimulated DLD-1 colon cancer cells was 27.2 cells/field of view, whereas for PSK-stimulated DLD-1 colon cancer cells, it was 8.8 cells/field of view, a significantly lower rate of adhesion to HUVEC. 


\section{Discussion}

Polysaccharide K (PSK), a protein-bound polysaccharide, is a widely used, non-specific immunotherapeutic agent that is obtained from Corillus versicolor fungi (9). It basically acts as a biochemical response modifier and possesses a diverse range of immunostimulating effects, including activating lymphocyte proliferation and enhancing lymphokine production (25-27). In research on mice, Kobayashi et al implanted Lewis lung carcinoma subcutaneously and found that metastasis to the lung was suppressed by peritoneal administration of PSK (28), while Hosokawa et al administered PSK before or after surgery on mice with induced autologous tumor lineages and reported that survival time was extended compared with mice that had undergone the surgical procedure only (29). A number of reports have also indicated its clinical efficacy for malignant tumors of the digestive tract, particularly gastric and colon cancers (14-17). In terms of clinical results with respect to human colon cancer, Torisu et al (14), Sakamoto et al (15) and Ohwada et al (16) have reported significantly improved survival rates as a result of PSK administration to patients undergoing curative resection, compared with patients who did not receive PSK. It is thus clear that PSK acts effectively as a therapeutic agent, but most reports concerning its mechanism of action have focused on normal cells other than cancer cells, examining how it acts on the immune response in a variety of healthy mice or human tissues $(5,6)$ and there have been almost no studies of the morphological changes to cancer cells themselves or of their molecular biology. In the present study, we investigated the way in which PSK stimulation acts on colon cancer cells themselves. As shown in Fig. 1, clear changes in cellular morphology were observed, leading to the discovery that PSK has an effect on the skeletal system of the cells.

Liver metastasis is generally regarded as a prognostic factor in colon cancer. The mechanism whereby liver and hematogenous metastases of colon cancer occur involves cancer cells breaking off the primary lesion, after which they penetrate the capillaries and spread throughout the body via the portal and greater circulatory systems. They then adhere to vascular endothelial cells at the target organ, escape from the blood vessel, infiltrate the area outside and proliferate at the metastatic site. As a result of the elucidation of this mechanism of metastasis in recent years, it has been reported that molecules such as cellular adhesion molecules and angiogenic growth factors are important (30).

We therefore focused on adhesion to vascular endothelial cells at target organs as the first stage in metastasis to a distant organ and investigated what changes occurred to adhesion molecules and adhesion of colon cancer cells after PSK stimulation. The reduction in the adhesion rate was observed for laminin, fibrinogen, collagen IV, collagen I and fibronectin. These proteins are a constituent of basement membranes together with nidogen and heparan sulfate proteoglycan, and reported to be involved in neurite growth and cell adhesion, proliferation, differentiation and migration $(31,32)$. Integrin is the best-known ligand for the proteins of basement membranes (33) and has been implicated by a number of reports in liver metastasis of colon cancer (34). We investigated the changes that are caused by PSK stimulation to the expression of integrin mRNA in colon cancer cells. As shown in Fig. 4, the expression of integrin mRNA decreased. We also investigated the adhesiveness between vascular endothelial cells and PSK-stimulated colon cancer cells. Compared with cells not exposed to PSK, their adhesiveness was significantly lower, indicating that PSK acts on colon cancer cells, lowering their adhesion to vascular endothelial cells by reducing cell adhesion molecules (Fig. 6).

\section{References}

1. Japanese Society for Cancer of the Colon and Rectum: Multiinstitutional registry of large bowel cancer in Japan, cases treated in 1995-1998. Vol.17 (1999), Vol.18 (2000), Vol.21 (2001), Vol.24 (2003).

2. Heald RJ, Husband EM and Ryall RD: The mesorectum in rectal cancer surgery - the clue to pelvic recurrence? Br J Surg 69: 613-616, 1982.

3. Shah SA, Haddad R, Al-Sukhni W, Kim RD, Greig PD, Grant DR, Taylor BR, Langer B, Gallinger S and Wei AC: Surgical resection of hepatic and pulmonary metastases from colorectal carcinoma. J Am Coll Surg 202: 468-475, 2006.

4. Goldberg RM, Sargent DJ, Morton RF, Fuchs CS, Ramanathan RK, Williamson SK, Findlay BP, Pitot HC and Alberts SR: A randomized controlled trial of fluorouracil plus leucovorin, irinotecan, and oxaliplatin combinations in patients with previously untreated metastatic colorectal cancer. J Clin Oncol 22: 23-30, 2004.

5. Tournigand C, André T, Achille E, Lledo G, Flesh M, Mery-Mignard D, Quinaux E, Couteau C, Buyse M, Ganem G, Landi B, Colin P, Louvet C and de Gramont A: FOLFIRI followed by FOLFOX6 or the reverse sequence in advanced colorectal cancer: a randomized GERCOR study. J Clin Oncol 22: 229-237, 2004.

6. Saltz LB, Clarke S, Díaz-Rubio E, Scheithauer W, Figer A, Wong R, Koski S, Lichinitser M, Yang TS, Rivera F, Couture F, Sirzén F and Cassidy J: Bevacizumab in combination with oxaliplatin-based chemotherapy as first-line therapy in metastatic colorectal cancer: a randomized phase III study. J Clin Oncol 26: 2013-2019, 2008

7. Bosset JF, Collette L, Calais G, Mineur L, Maingon P, Radosevic-Jelic L, Daban A, Bardet E, Beny A and Ollier JC; EORTC Radiotherapy Group Trial 22921: Chemotherapy with preoperative radiotherapy in rectal cancer. N Engl J Med 355: 1114-1123, 2006.

8. Gérard JP, Conroy T, Bonnetain F, Bouché O, Chapet O, Closon-Dejardin MT, Untereiner M, Leduc B, Francois E, Maurel J, Seitz JF, Buecher B, Mackiewicz R, Ducreux M and Bedenne L: Preoperative radiotherapy with or without concurrent fluorouracil and leucovorin in T3-4 rectal cancers: results of FFCD 9203. J Clin Oncol 24: 4620-4625, 2006.

9. Tsukagoshi S, Hashimoto Y, Fujii G, Kobayashi H, Nomoto K and Orita K: Krestin (PSK). Cancer Treat Rev 11: 131-155, 1984.

10. Araya S, Nio Y, Hayashi H, Masai Y, Tsubono M, Ishigami S and Imamura M: Various plant-derived polysaccharides augment the expression of HLA on Colo205 human colonic cancer line. J Jpn Soc Cancer Ther 29: 1965-1973, 1994.

11. Hirose K, Zachariae CO, Oppenheim JJ and Matsushima K: Induction of gene expression and production of immunomodulating cytokines by PSK in human peripheral blood mononuclear cells. Lymphokine Res 9: 475-483, 1990.

12. Algarra I, Collado A, Garcia Lora A and Garrido F: Differential effect of protein-bound polysaccharide (PSK) on survival of experimental murine tumors. J Exp Clin Cancer Res 18: 39-46, 1999.

13. Harada M, Matsunaga K, Oguchi Y, Iijima H, Tamada K, Abe K, Takenoyama M, Ito O, Kimura G and Nomoto K: Oral administration of PSK can improve the impaired anti-tumor $\mathrm{CD}^{+} \mathrm{T}$-cell response in gut-associated lymphoid tissue (GALT) of specificpathogen-free mice. Int J Cancer 70: 362-372, 1997.

14. Torisu M, Hayashi Y, Ishimitsu T, Fujimura T, Iwasaki K, Katano M, Yamamoto H, Kimura Y, Takesue M, Kondo M, et al: Significant prolongation of disease-free period gained by oral polysaccharide K (PSK) administration after curative surgical operation of colorectal cancer. Cancer Immunol Immunother 31: 261-268, 1990. 
15. Sakamoto J, Morita S, Oba K, Matsui T, Kobayashi M, Nakazato $\mathrm{H}$ and Ohashi Y; Meta-Analysis Group of the Japanese Society for Cancer of the Colon Rectum: Efficacy of adjuvant immunochemotherapy with polysaccharide $\mathrm{K}$ for patients with curatively resected colorectal cancer: a metaanalysis of centrally randomized controlled clinical trials. Cancer Immunol Immunother 55: 404-411, 2006.

16. Ohwada S, Ikeya T, Yokomori T, Kusaba T, Roppongi T, Takahashi T, Nakamura S, Kakinuma S, Iwazaki S, Ishikawa H, Kawate S, Nakajima T and Morishita Y: Adjuvant immunochemotherapy with oral Tegaful/Uracil plus PSK in patients with stage II or III colorectal cancer: a randomized controlled study. Br J Cancer 90: 1003-1010, 2004.

17. Yoshitani S and Takashima S: Efficacy of postoperative UFT (Tegafur/Uracil) plus PSK therapies in elderly patients with resected colorectal cancer. Cancer Biother Radiopharm 24: 35-40, 2009.

18. Shibata M, Nezu T, Fujisaki S, Andou K, Tomita R and Fukuzawa M: Clinical potential of biological response modifiers combined with chemotherapy for gastric cancer. Japanese experience. Dig Surg 19: 255-260, 2002.

19. Oba K, Teramukai S, Kobayashi M, Matsui T, Kodera Y and Sakamoto J: Efficacy of adjuvant immunochemotherapy with polysaccharide $\mathrm{K}$ for patients with curative resections of gastric cancer. Cancer Immunol Immunother 56: 905-911, 2007.

20. Ogoshi K, Satou H, Isono K, Mitomi T, Endoh M and Sugita M: Immunotherapy for esophageal cancer. A randomized trial in combination with radiotherapy and radiochemotherapy. Cooperative Study Group for Esophageal Cancer in Japan. Am J Clin Oncol 18: 216-222, 1995.

21. Morimoto T, Ogawa M, Orita K, Sugimachi K, Toge T, Dohi K, Nomura Y, Monden Y and Ogawa N: Postoperative adjuvant randomised trial comparing chemoendocrine therapy, chemotherapy and immunotherapy for patients with stage II breast cancer: 5-year results from the Nishinihon Cooperative Study Group of Adjuvant Chemoendocrine Therapy for Breast Cancer (ACETBC) of Japan. Eur J Cancer 32A: 235-242, 1996.

22. Hayakawa K, Mitsuhashi N, Saito Y, Nakayama Y, Furuta M, Nakamoto S, Kawashima M and Niibe H: Effect of Krestin as adjuvant treatment following radical radiotherapy in non-small cell lung cancer patients. Cancer Detect Prev 21: 71-77, 1997.
23. Sato T, Yamaguchi A, Goi T, Hirono Y, Takeuchi K, Katayama K and Matsukawa S: Heparanase expression in human colorectal cancer and its relationship to tumor angiogenesis, hematogenous metastasis and prognosis. J Surg Oncol 87: 174-181, 2004.

24. Goi T, Yamaguchi A, Nakagawara G, Urano T, Shiku H and Furukawa K: Reduced expression of deleted colorectal carcinoma (DCC) protein in established colon cancers. Br J Cancer 77: 466-471, 1998.

25. Fisher M and Yang LX: Anticancer effects and mechanisms of polysaccharide-K (PSK): implications of cancer immunotherapy. Anticancer Res 22: 1737-1754, 2002.

26. Asai H, Iijima H, Matsunaga K, Oguchi Y, Katsuno H and Maeda K: Protein-bound polysaccharide K augments IL-2 production from murine mesenteric lymph node $\mathrm{CD} 4^{+} \mathrm{T}$ cells by modulating $\mathrm{T}$ cell receptor signaling. Cancer Immunol Immunother 57: 1647-1655, 2008.

27. Kato M, Hirose K, Hakozaki M, Ohno M, Saito Y, Izutani R, Noguchi J, Hori Y, Okumoto S, Kuroda D, et al: Induction of gene expression for immunomodulating cytokines in peripheral blood mononuclear cells in response to orally administered PSK, an immunomodulating protein-bound polysaccharide. Cancer Immunol Immunother 40: 152-156, 1995.

28. Kobayashi H, Matsunaga K and Oguchi Y: Antimetastatic effects of PSK (Krestin), a protein-bound polysaccharide obtained from basidiomycetes: an overview. Cancer Epidemiol Biomarkers Prev 4: 275-281, 1995.

29. Hosokawa M, Mizukoshi T, Sugawara M and Kobayashi H: Therapeutic effects of PS-K and busulfan on the recurrent and metastatic diseases after the surgical removal of 3-methylcholanthrene-induced autochthonous tumors in C57BL/6 mice. Jpn J Cancer Res 76: 61-67, 1985.

30. Fidler IJ and Ellis LM: The implications of angiogenesis for the biology and therapy of cancer metastasis. Cell 79: 185-188, 1994.

31. Heino J and Käpylä J: Cellular receptors of extracellular matrix molecules. Curr Pharm Des 15: 1309-1317, 2009.

32. Kramer JM: Basement membranes. WormBook 1: 1-15, 2005.

33. van der Flier A and Sonnenberg A: Function and interactions of integrins. Cell Tissue Res 305: 285-298, 2001.

34. Paschos KA, Canovas D and Bird NC: The role of cell adhesion molecules in the progression of colorectal cancer and the development of liver metastasis. Cell Signal 21: 665-674, 2009. 